\title{
DEVELOPING GABILPANET-BASED NUMBER LINE LEARNING MEDIA TO ENHANCE ELEMENTARY SCHOOL STUDENTS' UNDERSTANDING OF THE CONCEPT OF INTEGERS COUNTING OPERATION AT GRADE VI
}

\author{
Farida Zakiah $^{1}$, Sukirman ${ }^{2}$, Sri Utaminingsih ${ }^{3}$ \\ 1,2,3 Universitas Muria Kudus, Indonesia \\ Izakiahfarida@gmail.com, ${ }^{2}$ sukirman@umk.ac.id, ${ }^{3}$ sri.utaminingsih@umk.ac.id
}

\begin{abstract}
The purpose of this research was to analyze the effectiveness of gabilpanet-based number line learning media to enhance elementary school students understanding of the concept of integer counting operations at grade IV in Kabupaten Jepara. This research was a development research using Borg \& Gall model. The development steps included: 1) researching the existing products, 2) studying the literature, 3) planning the product development, 4) designing the product, 5) conducting limited trial, 6) conducting main field trial, 7) conducting operational field trial. The subjects of this study were sixth grade students at SDN 4 Tulakan, SDN 2 Bandungharjo, SDN 3 Bandungharjo, and SDN 4 Bandungharjo. Data were collected through observation, questionnaires, tests, and interviews. Then, the validation results were analyzed by accumulating the scores and the statistical test of the effectiveness was carried out with SPSS version 26. Data on the effectiveness of gabilpanet-based number line learning media were analyzed through normality and homogeneity tests at a significance level of 0.05 . The finding revealed that gabilpanet-based number line learning media was effective and useful to be utilized in learning activities in order to enhance studetns' understanding of the concept of integer counting operations. Based on the data obtained, the average score of students' learning activities was 0.76 with a percentage of $76 \%$. Moreover, the result of students' learning outcome based on the average score of $n$-Gain was 0.69 with an average pre-test score of 43.00 and the average post test 82.50 .
\end{abstract}

Keywords: learning media, gabilpanet, integers counting operation

\section{PENGEMBANGAN MEDIA PEMBELAJARAN GARIS BILANGAN BERBASIS GABILPANET UNTUK MEMBANGUN PEMAHAMAN KONSEP OPERASI HITUNG BILANGAN BULAT PADA SISWA KELAS VI SEKOLAH DASAR}

\begin{abstract}
ABSTRAK
Tujuan dari penelitian dan pengembangan ini yaitu menganalisis keefektifan media pembelajaran garis bilangan berbasis gabilpanet untuk membangun pemahaman konsep operasi hitung bilangan bulat siswa kelas VI sekolah dasar di Kabupaten Jepara. Penelitian ini merupakan penelitian pengembangan menggunakan model Borg \& Gall. Langkah-langkah pengembangan yang dilaksanakan meliputi: 1) penelitian terhadap produk yang telah ada, 2) studi literatur, 3) perencanaan pengembangan produk, 4) pembuatan produk, 5) uji coba terbatas, 6) uji coba lapangan utama, 7) uji coba lapangan operasionanal. Subjek penelitia ini adalah siswa kelas VI SDN 4 Tulakan, SDN 2 Bandungharjo, SDN 3 Bandungharjo, dan SDN 4 Bandungharjo. Data dikumpulkan melalui observasi, angket, tes, dan wawancara. Hasil validasi dianalisis dengan mengakumulasikan jumlah skor. Uji statistik keefektifan dilakukan dengan SPSS 26 version. Data keefektifan media pembelajaran garis bilangan berbasis gabilpanet dianalisis dengan uji normalias dan homogenitas pada taraf signifikansi 0.05 . Penggunaan media pembelajaran garis bilangan berbasis gabilpanet ini efektif dan bermanfaat untuk digunakan siswa dalam kegiatan pembelajaran untuk membangun pemahaman konsep operasi hitung bilangan bulat. Berdasarkan data perolehan jumlah skor rata-rata aktivitas belajar siswa sebersar 0.76 dengan persentase $76 \%$ dan hasil belajar siswa dengan mencari rata-rata nilai n-Gain diperoleh nilai sebesar 0,69 dengan perolehan rata-rata nilai pre tes 43.00 dan post tes 82.50 .
\end{abstract}

Kata Kunci: media pembelajaran, gabilpanet, operasi hitung bilangan bulat

\begin{tabular}{|c|c|c|}
\hline Submitted & Accepted & Published \\
\hline 05 Maret 2021 & 19 Juli 2021 & 28 Juli 2021 \\
\hline
\end{tabular}

\begin{tabular}{|l|l|r|}
\hline Citation & $:$ & $\begin{array}{r}\text { Zakiah, F., Sukirman., \& Utaminingsih, S. (2021). Developing Gabilpanet-Based Number Line Learning Media to Enhance } \\
\text { Elementary School Students' Understanding of the Concept of Integers Counting Operation at Grade VI. Jurnal } \\
\text { PAJAR (Pendidikan dan Pengajaran), 5(4), 1085-1093. DOI : http://dx.doi.org/10.33578/pjr.v5i4.8353. }\end{array}$ \\
\hline
\end{tabular}

\section{PENDAHULUAN}

Matematika adalah mata pelajaran yang dipelajari oleh peserta didik dari tingkat sekolah dasar hingga perguruan tinggi. Patut disadari bahwa matematika sangat berperan dalam kehidupan sehari-hari. Salah satu perannya adalah belajar matematika dapat membuat siswa berfikir 
kritis, kreatif, dan aktif (Swintari, 2016: 90). Belajar matematika bertujuan untuk mengembangkan dan memperdalam pemahaman tentang konsep dan hubungan matematika ketika mereka membuat, membandingkan, dan menggunakan berbagai representasi (Salam, 2020: 1005).

Pendidikan yang dibangun di atas kompetensi abad 21 menitikberatkan pada pembelajaran yang menuntut peserta didik memiliki keterampilan, pengetahuan, pemahaman konsep, dan kemampuan di bidang teknologi, media, dan informasi. Salah satu keterampilan yang dibutuhkan untuk menghadapi revolusi industri adalah memahami konsep matematika (Huda, 2019: 261).

Pembelajaran matematika di SD masih terdapat banyak masalah, baik dari segi siswa, guru, maupun cara penyampaiannya. Demikian pula yang dialami peneliti di SD Negeri 3 Bandungharjo, Kecamatan Donorojo, Kabupaten Jepara, beberapa masalah muncul dalam pembelajaran. Dalam mata pelajaran matematika kelas VI nilai siswa selalu rendah, terutama yang berkaitan tentang operasi hitung bilangan bulat. Siswa kesulitan dalam menyelesaikan soal operasi hitung bilangan bulat seperti penjumlahan, pengurangan, perkalian, dan pembagian.

Keterampilan berhitung siswa sangat rendah. Terlebih dalam operasi hitung bilangan bulat. Ini disebabkan karena: (1) siswa tidak mampu memahami konsep operasi hitung bilangan bulat; (2) siswa kurang menyukai pelajaran matematika; (3) siswa tidak menyukai metode pembelajaran yang digunakan guru; (4) tidak adanya media pembelajaran yang menarik.

Secara umum, nilai hasil belajar siswa kelas VI mata pelajaran matematika di di SDN 3 Bandungharjo Kecamatan Donorojo Kabupaten Jepara di bawah KKM. Baik nilai harian, nilai ulangan harian, nilai mid semester, dan akhir semester. Bahkan nilai Ujian Akhir Sekolah juga tidak sesuai harapan. Ini merupakan suatu tantangan bagi guru, karena nilai pada mata pelajaran matematika tidak berhasil untuk mencapai hasil yang telah di tentukan, yakni di atas KKM.
Untuk mengatasi permasalahan tersebut, maka peneliti membuat media pembelajaran Gabilpanet. Media Gabilpanet merupakan pengembangan media garis bilangan untuk membangun pemahaman konsep operasi hitung bilangan bulat pada siswa kelas VI Sekolah Dasar.

Media Gabilpanet adalah sebuah alat dan bahan media visual yang dapat dipakai untuk penyampaian pesan mencapai tujuan pendidikan yang memungkinkan siswa memperoleh pengetahuan, keterampilan, dan sikap. Melalui media tersebut diharapkan dapat membangun pemahaman konsep operasi hitung bilangan bulat dengan baik. Melalui Gabilpanet ini siswa diarahkan untuk memahami pelajaran melalui benda kongkrit sehingga membantu pemahaman siswa terhadap materi yang mereka pelajari.

\section{METODE PENELITIAN}

Penelitian berorientasi pada pengembangan media pembelajaran garis bilangan berbasis gabilpanet untuk membangun pemahaman konsep operasi hitung bilangan bulat. Desain pengembangan mengadaptasi model Borg and Gall. Penelitian ini mengambil 7 langkah, yaitu: penelitian produk yang telah ada, penelitian dan pengumpulan informasi, perencanaan, mengembangan produk awal, pengujian lapangan awal, uji coba lapangan utama, uji coba lapangan operasional.

Teknik pengumpulan data dalam penelitian ini dilakukan dengan tes, wawancara, observasi, kuisoner, dan dokumentasi.

\section{HASIL DAN PEMBAHASAN \\ Hasil Validasi Ahli}

Data kevalidan pengembangan media garis bilangan berbasis gabilpanet untuk membangun pemahaman konsep operasi hitung bilangan bulat diperoleh melalui angket validasi. Data yang dikumpulkan berupa skor penilaian terkait kelayakan pengembangan media garis bilangan berbasis gabilpanet dalam materi operasi hitung bilangan bulat siswa SD. Oleh karena itu, sebelum menyajikan data kevalidan pembelajaran berbasis gabilpanet, terlebih dahulu disajikan data survei kebutuhan pembelajaran matematika berbasis gabilpanet. 
Hasil survei kebutuhan pembelajaran matematika berbasis gabilpanet kepada 63 siswa di SDN 4 Tulakan, SDN 2 Bandungharjo, SDN 3 Bandungharjo, SDN 4 Bandungharjo dan 4 orang guru kelas VI di empat sekolah dasar disajikan dalam tabel 1 berikut.

Tabel 1. Responden Siswa Dan Guru

\begin{tabular}{ccc}
\hline Responden & Persentase & Kategori \\
\hline Siswa & $83.75 \% \%$ & Butuh \\
\hline Guru & $75 \%$ & Butuh
\end{tabular}

Berdasarkan Tabel 1 dijelaskan bahwa kebutuhan pembelajaran matematika materi operasi hitung bilangan bulat mengggunakan media gabilpanet sangat tinggi. Hal itu terlihat dari angket yang diberikan kepada 63 siswa di SDN 4 Tulakan, SDN 2 Bandungharjo, SDN 3 Bandungharjo, dan SDN 4 Bandungharjo menyatakan butuh dan 4 guru kelas VI di SDN 4 Tulakan, SDN 2 Bandungharjo, SDN 3 Bandungharjo, dan SDN 4 Bandungharjo menyatakan butuh media gabilpanet dalam pembelajaran operasi hitung bilangan bulat.
Evaluasi juga diberikan berkaitan dengan produk yang dikembangkan. Oleh karena itu, aspek yang dinilai berkaitan dengan kelayakan pembelajaran matematika berbasis gabilpanet dan penggunaan media dalam pembelajaran. Penilaian oleh para ahli dikumpulkan untuk mengetahui hasil evaluasi serta masukan untuk perbaikan produk. Penilaian diberikan dalam bentuk skor dengan kisaran 1 sampai 4. Validasi ahli materi meliputi aspek yang terdiri dari 15 indikator. Validasi ahli media meliputi aspek yang terdiri dari 10 indikator. Adapun skor kriteria validasi penilaian dapat dilihat pada Tabel. 2 berikut.

Tabel 2. Skor Kriteria Validasi

\begin{tabular}{ccl}
\hline Skor & Kriteria & \multicolumn{1}{c}{ Arti } \\
\hline \multirow{2}{*}{$0.00-1.00$} & $\begin{array}{c}\text { Sangat } \\
\text { Tidak Baik }\end{array}$ & $\begin{array}{l}\text { Tidak baik sehingga tidak dapat digunakan, } \\
\text { masih memerlukan konsultasi dan perbaikan }\end{array}$ \\
\hline \multirow{2}{*}{$1.01-2.00$} & Tidak baik & $\begin{array}{l}\text { Kurang baik sehingga belum dapat digunakan, } \\
\text { masih memerlukan konsultasi dan perbaikan }\end{array}$ \\
\hline \multirow{2}{*}{$2.01-3.00$} & Baik & Baik sehingga dapat digunakan dengan \\
& & berbaikan sesuai saran \\
\hline $3.01-4.00$ & Sangat & Sangat baik sehingga dapat digunakan meskipun \\
& baik & masih ada perbaikan \\
\hline
\end{tabular}

Kriteria validasi ahli materi dan ahli media dapat ditentukan dengan rumus:

Rata rata Skor Hasil Penilaian = Jumlah Skor Penilaian
Berikut hasil penilaian yang diberikan para validator terhadap produk yang dikembangkan pada tabel 3 berikut. Jumlah Indikator 
Tabel 3. Skor Hasil Penilaian

\begin{tabular}{ccc}
\hline Validator & $\begin{array}{c}\text { Jumlah Skor Hasil } \\
\text { Penilaian }\end{array}$ & Kriteria \\
\hline $\begin{array}{c}\text { Validator } \\
\text { I }\end{array}$ & 3.73 & Sangat Baik \\
\hline $\begin{array}{c}\text { Validator } \\
\text { II }\end{array}$ & 3.60 & Sangat Baik \\
\hline
\end{tabular}

Dari tabel 3 diperoleh skor hasil penilaian rata-rata yang diberikan oleh validator I dan II masing-masing 3.73 dan 3.60 dengan kategori sangat baik. Berdasarkan data tersebut maka pengembangan media pembelajaran garis bilangan berbasis gabilpanet untuk membangun operasi hitung bilangan bulat ini layak digunakan.

\section{Uji Coba Lapangan}

Uji coba lapangan dilakukan di 4 Sekolah Dasar di Kabupaten Jepara, yaitu siswa kelas VI SDN 4 Bandungharjo SDN 4 Tulakan, SDN 2 Bandungharjo, dan SDN 3 Bandungharjo. Subyek penelitian sebanyak 11 siswa pada kelas kontrol dari siswa SDN 4 Bandungharjo, 52 siswa kelas eksperimen yang terdiri dari 17 siswa SDN 4 Tulakan, 13 siswa SDN 2 Bandungharjo dan 22 siswa SDN 3 Bandungharjo.

Analisis hasil belajar siswa secara sederhana dengan melakukan pre-test dan pos-test.
Pengembangan media pembelajaran garis bilangan berbasis gabilpanet ini juga dianalisis keefektifannya pada uji lapangan dengan mencari rata rata nilai $n$-Gain.

Uji Normalitas Gain atau n-gain menurut hake dalam Sundayana (2016) mengemukakan $n$ gain adalah sebuah uji yang bisa memberikan gambaran umum peningkatan skor hasil pembelajaran antara sebelum dan sesudah diterapkannya metode tersebut. Data pre-test dan postes dianalisis dengan melihat Gain ternormalisasi yang dihitung dengan rumus:

$\mathbf{N}-$ Gain $=\frac{\text { nilai postes }- \text { nilai } \text { pretes }}{\text { nilai maksimal-nilai pretes }}$

Sumber: Setiawan MA,dkk (2016:747)

Kriteria $N$-Gain dari Hake dapat dilihat pada Tabel 4 berikut:

Tabel 4. Kriteria N-Gain

\begin{tabular}{cc}
\hline Nilai N-Gain & Kriteria \\
\hline $\mathrm{N}$-gain $<0.3$ & rendah \\
\hline $0.3 \leq \mathrm{N}$-gain $<0.7$ & Sedang \\
\hline $0.7 \leq \mathrm{N}$-gain & Tinggi \\
\hline
\end{tabular}

Hasil perolehan nilai pada pre-test dan post-tes dapat dihitung secara manual nilai $n$-gain data sebagai berikut:

$$
\begin{aligned}
& \mathbf{N}-\text { Gain } \quad=\frac{79.09-51.81}{100-51.81} \\
& =\frac{27.28}{48.19}
\end{aligned}
$$

$$
=0.566
$$

Dari perhitungan di atas diperoleh data seperti pada tabel 5 berikut: 


\begin{tabular}{cccc}
\multicolumn{4}{c}{ Tabel 5. } \\
\hline $\begin{array}{c}\text { Rata Rata } \\
\text { Nilai Pre-Test }\end{array}$ & $\begin{array}{c}\text { Rata Rata } \\
\text { Nilai Postest }\end{array}$ & $\begin{array}{c}\text { Nilai } \\
\text { Maksimal }\end{array}$ & $\begin{array}{c}\text { Rata Rata } \\
\text { N-Gain }\end{array}$ \\
\hline 51.81 & 79.09 & 100.00 & 0.566
\end{tabular}

Berdasarkan tabel kriteria n-gain Hake maka dapat disimpulkan bahwa hasil belajar siswa dengan pengembangan media pembelajaran garis bilangan berbasis gabilpanet untuk membangun operasi hitung bilangan bulat berada pada kategori sedang.

\section{Hasil Analisis Uji Keefektivan Uji Normalitas}

Uji normalitas data adalah bentuk pengujian tentang kenormalan distribusi data. Tujuan dari uji ini adalah untuk mengetahui apakah data yang terambil merupakan data terdistribusi normal atau bukan. Maksud dari terdistribusi normal adalah data akan mengikuti bentuk distribusi normal di mana data memusat pada nilai rata-rata dan median. Dari penghitungan dengan SPSS 26 diperoleh data pada tabel 6 sebagai berikut.:

Tabel 6. Hasil Uji normalitas

\begin{tabular}{ccccccccc}
\hline & Kelompok & \multicolumn{3}{c}{ Kolmogorov-Smirnov } & \multicolumn{3}{c}{ Shapiro-Wilk } \\
\cline { 3 - 8 } & & \multicolumn{2}{c}{ Statistic } & df & Sig. & Statistic & df & Sig. \\
\hline \multirow{2}{*}{ Postets } & Eksperimen & .172 & 22 & .089 & .918 & 22 & .070 \\
\cline { 2 - 8 } & Kontrol & .219 & 11 & .146 & .889 & 11 & .134
\end{tabular}

Berdasarkan tabel 6 diketahui nilai df kelompok eksperimen adalah 22 dan kelompok control adalah 11 artinya jumlah sampel masing masing kelompok kurang dai 50 sehingga penggunaan Teknik Shapiro wilk untuk mendeteksi kenormalan data bisa dikatakan tepat.

Dari output juga diketahui nilai Sig. kelompok ekperimen sebesar 0.070 dan kelompok control 0.134. karena nilai kedua kelompok tersebut > 0.05 maka disimpulkan bahwa data hasil belajar kelompok eksperimen dan kelompok control terdistribusi normal

\section{Uji Homogenitas}

Setelah dilakukan Uji Normalitas, nilai pre-test juga dianalisis dengan Uji Homogenitas.

Uji homogenitas digunakan unutk mengetahui apakah hasil belajar kedua kelas sama. Dasar pengambilan keputusan uji homogenitas adalah:

1. Jika nilai signifikan atau sig. $<0.05$ maka dikatakan varian dari dua tidak sama (tidak homogen)

2. Jika nilai signifikan atau sig.> 0.05 maka dikatakan varian dari dua sama (homogen)

Dari penghitungan dengan SPSS 26 diperoleh data pada tabel 7 berikut: 
Jurnal PAJAR (Pendidikan dan Pengajaran)

Volume 5 Nomor 3 April 2021 | ISSN Cetak : 2580 - 8435 | ISSN Online : 2614 - 1337

DOI : http://dx.doi.org/10.33578/pjr.v5i4.8353

Tabel 7. Uji Homogenitas

\begin{tabular}{llrrrr}
\hline & Levene Statistic & df1 & df2 & Sig. \\
\hline Postest & Based on Mean & .509 & 1 & 31 & .481 \\
\cline { 2 - 6 } & Based on Median & .481 & 1 & 31 & .493 \\
\cline { 2 - 6 } & Based on Median and with & .481 & 1 & 29.891 & .493 \\
& adjusted off & & & & \\
\cline { 2 - 6 } & Based on trimmed mean & .535 & 1 & 31 & .470 \\
\hline Pretest & Based on Mean & .258 & 1 & 31 & .615 \\
\cline { 2 - 6 } & Based on Median & .138 & 1 & 31 & .715 \\
\cline { 2 - 6 } & Based on Median and with & .138 & 1 & 28.925 & .715 \\
& adjusted off & & & & .745 \\
\cline { 2 - 6 } & Based on trimmed mean & .108 & 1 & 31 & \\
\cline { 2 - 6 }
\end{tabular}

Berdasarkan tabel 7 hasil uji homogenitas diketahui nilai signifikansi (Sig.) hasil belajar matematika kelompok eksperimen dan kelompok kontrol sebesar 0.481 karena $0.481>0.05$ maka disimpulkan bahwa varian data hasil belajar matematika pada kelas eksperimen dan kelas kontrol adalah sama atau homogen.

\section{Peningkatan Hasil Belajar Siswa (Uji Gain)}

Peningkatan hasil belajar siswa dianalisis dengan menggunakan rata-rata Gain ternormalisasi. Untuk mengetahui garis besar peningkatan hasil belajar siswa pada berikut rekapitulasi hasil pretes dan posttes kelas eksperiemn dan kelas kontrol pada tabel 8 berikut.

Tabel 8. Peningkatan Hasil Belajar

\begin{tabular}{|c|c|c|c|}
\hline \multirow[t]{2}{*}{ No } & \multirow[t]{2}{*}{ Variabel } & \multicolumn{2}{|r|}{ Skor } \\
\hline & & Kelas Kontrol & Kelas Eksperimen \\
\hline & Pretes & & \\
\hline 1 & Nilai terendah & 40 & 40 \\
\hline 2 & Nilai tertinggi & 60 & 80 \\
\hline 3 & Rata-rata & 51.81 & 51.81 \\
\hline & Posttest & & \\
\hline 1 & Nilai terendah & 50 & 60 \\
\hline 2 & Nilai tertinggi & 80 & 100 \\
\hline 3 & Rata-rata & 67.27 & 79.09 \\
\hline Gain & rnormaliasi & 0.32 (sedang) & 0.56 (sedang) \\
\hline
\end{tabular}

Peningkatan hasil belajar siswa ditampilkan pada garis gain ternormalisasi. Peningkatan rata-rata hasil belajar siswa pada kelas kontrol adalah 15.46 dan pada kelas eksperimen rata-rata peningkatannya sebesar 27.28. Nilai peningkatannya rata-rata lebih tinggi pada kelas eksperimen. Dengan demikian dapat disimpulkan bahwa media pembelajaran garis bilangan berbasis gabilpanet efektif untuk membangun konsep operasi hitung bilangan bulat yang dapat meningkatkan hasil belajar siswa pada aspek perkembangngan kognitif.

Efektivitas Pengembangan Media Pembelajaran Garis Bilangan Berbasis Gabilpanet untuk Membangun Pemahaman Konsep Operasi Hitung Bilangan Bulat

Keefektifan media pembelajaran garis bilangan berbasis gabilpanet untuk membangun pemahaman konsep operasi hitung bilangan bulat 
diperoleh melalui nilai rata-rata hasil belajar siswa dan rata-rata persentase aktivitas belajar siswa.
Kriteria kefektifan media pembelajaran dapat dilihat pada tabel 9 berikut.

Tabel 9. kriteria keefektifan media pembelajaran

\begin{tabular}{cll}
\hline No. & Indikator Keefektifan Pembelajaran & \multicolumn{1}{c}{ Kriteria Ketercapaian } \\
\hline 1 & $\begin{array}{l}\text { Skor peningkatan hasil belajar anak } \\
\text { dengan perhitungan n-gain }\end{array}$ & $\begin{array}{l}\text { Paling sedikit berada dalam kategori sedang }(\leq \\
0.30)\end{array}$ \\
2 & $\begin{array}{l}\text { Rata-rata persentase aktivitas belajar } \\
\text { anak }\end{array}$ & Paling sedikit dalam kategori baik \\
\hline
\end{tabular}

Rata-rata hasil belajar dapat dilihat pada tabel 10 berikut.

Tabel 10. Hasil Belajar Siswa

\begin{tabular}{|c|c|c|c|}
\hline \multirow[t]{2}{*}{ No } & \multirow[t]{2}{*}{ Variabel } & \multicolumn{2}{|c|}{ Skor } \\
\hline & & Kelas Eskperimen & Kelas Eksperimen \\
\hline & Pretes & & \\
\hline 1 & Nilai terendah & 30 & 40 \\
\hline 2 & Nilai tertinggi & 60 & 50 \\
\hline 3 & $\begin{array}{l}\text { Rata-rata } \\
\text { Posttest }\end{array}$ & 49.41 & 45.38 \\
\hline 1 & Nilai terendah & 70 & 70 \\
\hline 2 & Nilai tertinggi & 100 & 90 \\
\hline 3 & Rata-rata & 82.94 & 80.76 \\
\hline & Gain ternormal & 0.66 (sedang) & 0.64 (sedang) \\
\hline
\end{tabular}

Dari tabel 10 dapat dilihat rata-rata hasil belajar pada postest kelas ekperieman (SDN 4 Tulakan) yaitu 82.94, sedangkan rata-rata hasil belajar posttest pada kelas eksperimen (SDN 2
Bandungharjo) yaitu 80.76. Sehingga terlihat ada peningkatan pada dua kelas eksperimen. Hasil aktivitas belajar siswa dapat dilihat pada tabel 11 berikut.

Tabel 11. Aktivitas Belajar Siswa

\begin{tabular}{ccc}
\hline Kelas & Persentase & Kategori \\
\hline Kontrol (SDN 4 Bandungharjo) & $45.00 \%$ & Kurang \\
\hline Eksperimen (SDN 3 Bandungharjo) & $72.00 \%$ & Baik \\
\hline Eksperimen (SDN 4 Tulakan) & $76.47 \%$ & Baik \\
\hline Eksperimen (SDN 2 Bandungharjo) & $76.28 \%$ & Baik \\
\hline
\end{tabular}

Dari tabel 11 di atas persentase aktivitas pada kelas kontrol $45.00 \%$, sedangkan ketiga kelas eksperimen mencapai $72.00 \%, 76.47 \%$ dan $76.28 \%$ dengan kategori baik.

Berdasarkan data hasil yang diperoleh dari rata-rata hasil belajar dan aktivitas belajar siswa, maka pengembangan media pembelajaran garis bilangan berbasis gabilpanet efektif untuk membangun pemahaman konsep operasi hitung bilangan bulat.

\section{Pembahasan}

Ide dasar yang melandasi pembuatan pengembangan media pembelajaran garis bilangan berbasis gabilpanet ini adalah keterampilan berhitung siswa sangat rendah. Ini disebabkan karena siswa tidak mampu memahami konsep operasi hitung bilangan bulat, siswa kurang menyukai pelajaran matematika, siswa tidak menyukai metode pembelajaran, dan tidak ada 
media pembelajaran. Berdasarkan beberapa pengamatan di lapangan, maka peneliti mengambil suatu langkah untuk mengantisipasi masalah tersebut yang kemudian dijadikan sebagai sarana belajar untuk siswa dalam pembelajaran di sekolah.

Media pembelajaran garis bilangan berbasis gabilpanet ini dikembangkan untuk memudahkan siswa mempelajari konsep operasi hitung bilangan bulat. Media pembelajaran ini dikembangkan dengan menggunakan bahan kayu, papan bermagnet, mobil-mobilan, dan kertas. Garis besar pengembangan media pembelajaran garis bilangan berbasis gabilpanet ini adalah pembuatan medianya digunakan untuk membangun pemahaman konsep oeprasi hitung bilangan bulat. Dalam mengoperasikannya terdapat bekas goresan atau garis yang ada pada papan magnet jika mobil digerakkan. Hal ini memudahkan siswa untuk membangun konsep operasi hitung bilangan bulat dan dapat meningkatkan hasil belajar.

Penggunaan media pembelajaran garis bilangan berbasis gabilpanet terdapat kesepakatan, yaitu penjumlahan mobil maju, pengurangan mobil mundur, angka negatif menghadap ke kiri, angka positif menghadap ke kanan. Ini sesuai dengan pendapat Fajarwati (Darhim, 2001: 275) bahwa ada beberapa aturan penggunaan pita garis bilangan yang perlu dipahami adalah: 1) bila mobil-mobilan dilangkahkan maju berarti menambah, 2) bila mobil-mobilan dilangkahkan mundur berarti mengurangi, 3) bagian muka mobil-mobilan untuk arah positif, dan 4) bagian belakang mobil-mobilan untuk arah negatif. Keefektifan media pembelajaran garis bilangan berbasis gabilpanet untuk membangun pemahaman konsep operasi hitung bilangan bulat diperoleh melalui nilai rata-rata hasil belajar siswa dan ratarata persentase aktivitas belajar siswa.

Salah satu yang mendukung kegiatan pembelajaran dan juga berpengaruh terhadap hasil belajar siswa adalah penggunaan media pembelajaran. Media pembelajaran digunakan supaya kegiatan pembelajaran bervariasi dan menyenangkan serta lebih mengaktifkan siswa. Sehingga faktor internal dan ekternal diperlukan untuk memperoleh hasil belajar. Hal ini sesuai dengan pernyataan (Slameto, 2013) bahwa faktor internal adalah faktor dalam diri individu yang sedang belajar, sedangkan faktor eksternal adalah faktor yang ada di luar individu.

Berdasarkan data yang diperoleh, dapat dilihat rata-rata hasil belajar pada postest kelas ekperieman SDN 4 Tulakan. Rata-rata hasil belajar posttest pada kelas eksperimen SDN 2 Bandungharjo yaitu 80.76. Sehingga terlihat ada peningkatan pada dua kelas eksperimen. Hasil aktivitas belajar siswa dapat dilihat pada persentase aktivitas pada kelas kontrol $45.00 \%$, sedangkan ketiga kelas eksperimen mencapai $72.00 \%$, $76.47 \%$ dan $76.28 \%$ dengan kategori baik.

Berdasarkan data hasil yang diperoleh dari rata-rata hasil belajar dan aktivitas belajar siswa, maka pengembangan media pembelajaran garis bilangan berbasis gabilpanet efektif untuk membangun pemahaman konsep operasi hitung bilangan bulat. Hal ini sesuai dengan penelitian yang dilakukan oleh (Alawiyah, 2016) yang bertujuan untuk meningkatkan hasil belajar dan keaktifan belajar siswa pada mata pelajaran matematika dengan menggunakan media garis bilangan.

\section{SIMPULAN DAN REKOMENDASI}

Tingkat pemahaman konsep siswa tentang operasi hitung bilangan bulat siswa kelas VI di Jepara rendah. Untuk itu perlu adanya pengembangan media pembelajaran garis bilangan berbasis gabilpanet untuk membantu siswa membangun pemahaman konsep operasi hitung bilangan bulat siswa kelas VI sekolah dasar di Jepara.

Penggunaan media pembelajaran garis bilangan berbasis gabilpanet ini efektif dan bermanfaat untuk digunakan siswa dalam kegiatan pembelajaran yaitu untuk membangun pemahaman konsep operasi hitung bilangan bulat. Berdasarkan data perolehan jumlah skor rata-rata aktivitas belajar siswa sebersar 0.76 dengan persentase $76 \%$. Berdasarkan perhitungan hasil belajar siswa dengan mencari rata-rata nilai nGain kelas eksperimen SDN 4 Ttulakan diperoleh nilai sebesar 0,66 dengan perolehan rata-rata nilai pre tes 49.41 dan nilai post tes 82.594 . Sedangkan rata-rata nilai $\mathrm{n}$-Gain kelas eksperimen SDN 2 Bandungharjo diperoleh nilai sebesar 0.64 dengan 
perolehan rata-rata nilai pre tes 45.38 dan nilai post tes 80.76 .

Pengembangan media pembelajaran seharusnya terus ditingkatkan sebagai sarana untuk mempermudah siswa belajar memahami sebuah konsep. Media pembelajaran yang digunakan sebagai sarana untuk membantu siswa bmencapai tujuan pembelajaran sebaiknya memperhatikan prinsip kegunaan, keefektifan dan kebermanfaatan bagi siswa. dan pengembangan media pembelajaran garis bilangan berbasis gabilpanet ini dapat terus digunakan karena memiliki keefektifan dalam membangun pemahaman konsep operasi hitung bilangan bulat pada siswa sekolah dasar.

\section{DAFTAR PUSTAKA}

Alawiyah, N., dan Ichsan, M. (2017). Upaya Meningkatkan Hasil Belajar Matematika dengan Menggunakan Media Garis Bilangan. Didaktika Tauhidi. 4 (1), 4457.

Fajarwati, S. (2010). Model Pembelajaran Langsung Dengan Menggunakan Alat Peraga Pita Garis Bilangan Untuk Meningkatkan Partisipasi Aktif Siswa SD. Jurnal Pro Bisnis. 3 (1), 26-39.

Huda, S, dkk. (2019). Understanding of Mathematical Concepts in The Linier Equation With Two Variables: Impcat of E-Learning and Blended Learning Using Google Clasroom. Al-Jabar: Jurnal Pendidikan Matematika. 10 (2), 261270.

Salam, M., dkk. (2020). Effectiveness Of Integrative Learning Models in Improving Understanding Mathematical Concepts. Journal for The Education of Gifted Young Scientists. 8 (2), 10051014.

Swintari, S., \& Kade, A. (2016). Penerapan Model Pembelajaran Kooperatif Tipe STAD Berbantuan Garis Bilangan Untuk Meningkatkan Pemahaman Siswa Pada Perkalian Dan Pembagian Bilangan bulat Kelas VII SMP Avent Palu. Jurnal Elektronik Pendidikan Matematika Tadulako. 04 (01), 90-103. 